\title{
Learning The Arabic elements for elementary level \\ (Review of Approach, method, strategy and media)
}

\author{
Khotimatun Nafi'ah And R. Umi Baroroh \\ Sunan Kalijaga State Islamic University \\ muhazlakhotim@gmail.com
}

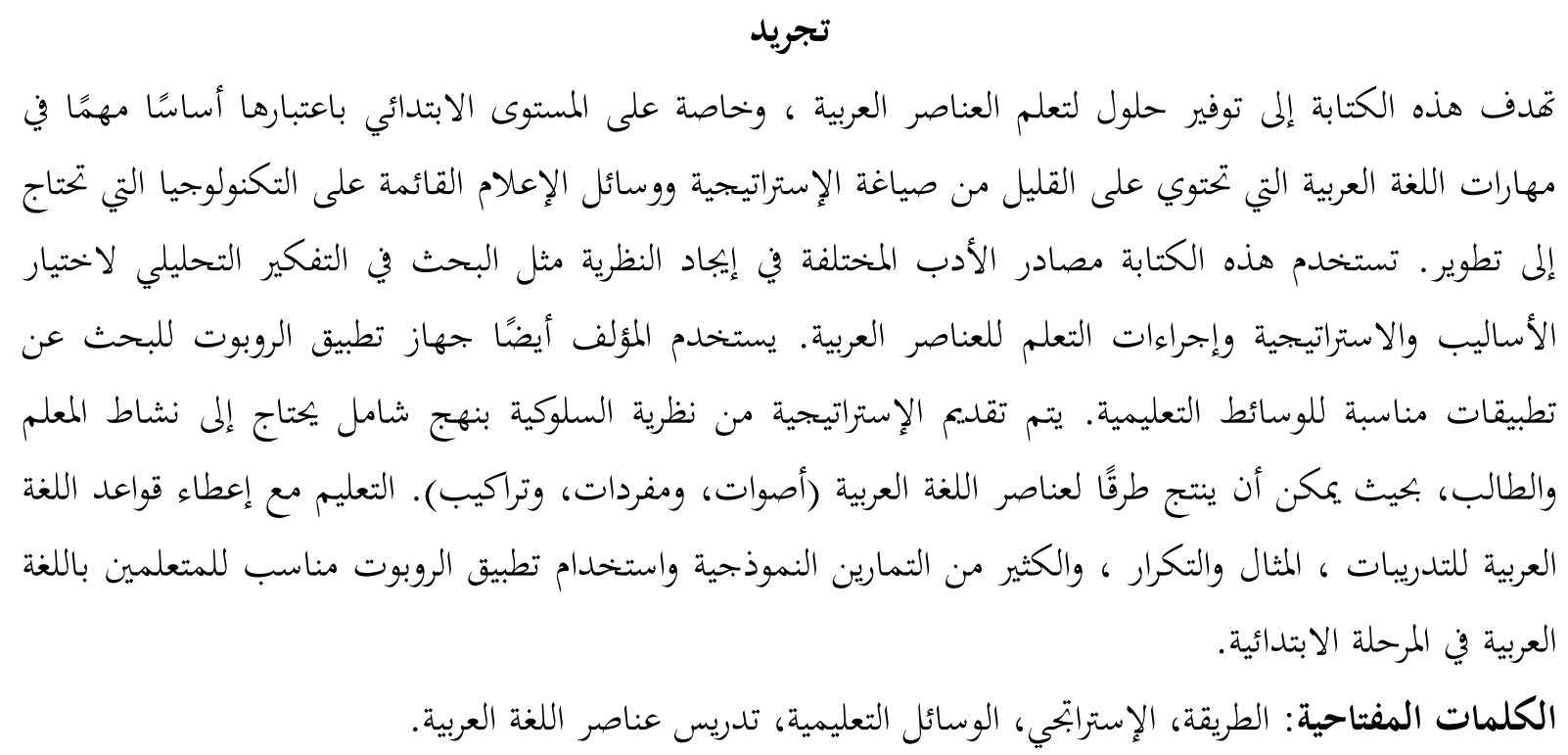

\section{A. Introduction}

Aside as religion, Arabic is one of world official languages so its learning is famous. Langauge is communication media that used by fellow for interaction and to share an idea that expressed by speaking or writing. ${ }^{1}$ Language as a communication media has given a responsibility to Arabic teacher for reaching the learning goals well. In general, the learning goals direct the students to use Arabic in oral and writing. Fauzan etc said that Arabic learning goals direct to: 1) Knowing the Arabic elements, there are a phonetic, vocabulary and idiom, and grammar 2) Using the arabic for effective communication 3) understanding the arabic culture, there are an idea, values, tradition, atittude, and art. ${ }^{2}$

To Reach a learning goals especially for knowing the arabic elements as the first construction in the arabic language, need a right composition. Choosing a strategy is needed in the learning as a media for reaching the learning goals and turn on a teaching and learning process. But the right strategy is one of the problems in Arabic learning. As Asse

1 Syaiful Mustofa, Strategi Pembelajaran Bahasa Arab Inovatif (Malang: UIN MALIKI PRESS, 2011), 3.

2 Ahmad Muradi, "Tujuan Pembelajaran Bahasa Asing (Arab) Di Indonesia," Al Maqoyis 1 (1), no. 1 (Juni 2013): 129 . 
said that one of the problems is found in a foreign language learning process and especially in Arabic learning, there is various of learning methods and strategies. ${ }^{3}$

Choosing learning method, strategy and media by the teacher is important part in the learning and for Arabic learning too. Arabic has an elements that need to be taught with a right method and strategy. There are Phonology (Ilm Ashwat), Ortography (Kitabat alhuruf), morphology (al-sharf), grammar (nachwu), and vocabulary (al-mufrodat). ${ }^{4}$

In Arabic learning has been applicated a strategy with visual media (picture) which interesting for students to keep enjoy in arabic learning, ${ }^{5}$ this strategy show that tacher's creaativity has been needed for supporting a succes learning. A lot of the learning strategies in vocabulary learning from elementary level, intermediate level and high level have been explained as reference for a teacher to teach the students, the example used a sing in elementary level, acted in intermediate level, and looked for meaning words in high level. 6 Explanation of that strategies is not enough to be understood without more spesific explanation about an idea which are imagined in the reader's mind spesific and clearly.

The arabic elements beside vocabulary is also phonetic (Al Ashwat) and grammar (qowaid). The phonetic has taught with synthetic mode (tarkibiyah), analytical (tahliliyah), and matched both, ${ }^{7}$ but who have given a deep idea about the phonetic teaching just a few and the explanation idea more about phonetic characteristic and phonetic teaching problems. The grammar also have taught with the various methods and strategies so that the students can accept a learning effectively. One of the methods has been inductive method used linguistics terms 8 that has explained qawaid learning in the example words so the students can understand that. Used that method is good but need more explanation about the conformity with the various level.

The various methods and strategies that have been applicated to the arabic elements learning need a clear and detail description so the teacher can use thats correctly. The right methods and strategies option now should give a space for the technology to parcitipate in the learning directly or indirectly. More detail explanation of the right methods and

3 Ahmad Asse, “Strategi Pembelajaran Bahasa Arab Di Insutut Agama Islam Negeri Palu," ISTIQRA 2 (2) (2 Desember 2014): 451.

4 Fuad Effendy, Metodologi Pengajaran Bahasa Arab (Malang: Misykat, 2009), 109.

5 sitti Hasnah, "Pembelajaran Kosakata (Mufradāt) Bahasa Arab Melalui Media Gambar Untuk Meningkatkan Minat Belajar Mahasiswa Pada Jurusan PAI Fakultas Tarbiyah Iain Palu," t.t., 222.

6 Widi Astuti, "Berbagai Strategi Pembelajaran Kosa Kata Bahasa Arab," Jurnal Komunikasi dan Pendidikan Islam 5 (1) (Desember 2016): 15.

7 Sugeng Riyadi, “Strategi Pembelajaran Bunyi Dan Mufrodat” 3, no. 2 (2014): 115.

8 Cahya Edi Setyawan, "PEMBELAJARAN QAWAID BAHASA ARAB MENGGUNAKAN METODE

INDUKTIF BERBASIS ISTILAH-ISTILAH LINGUISTIK," Jurnal Komunikasi dan Pendidikan Islam 4, no. 2

(Desember 2015): 15. 
strategies in the elements Aarabic learning needs a limit for more spesific. Focus of this paper is arabic elements learning for elementary level based on habitual or using behaviorism learning theory.

The behaviorism theory is a point of view which describes that a learning is behavior transformation as impact from interaction between stimulus and response. Application of the behaviorism theory to a learning is the teacher who is not just delivering a material in the lecturing but with an example too. A teaching material arranged hierarchily from the basic material to the complicated material. The expected result is formed a habbit that has been wished before. This theory is suitable to get the skills that need a practical and habituation. ${ }^{9}$

\section{B. Method}

The description gave a clear aim to explain the learning arabic elements method and strategy for elementary level based on behaviorism theory and focused to the function of the technology there. This paper used a various literatures as a foundation to look for theory that used for analytical thinking to choose a method, strategy and procedure in a learning about arabic elements, the main reference as a foundation to review a learning strategy and method which was suitable was the book by Syaiful Mustofa with the tittle "Strategi Pembelajaran Bahasa Arab Inovatif" and the book by R. Umi Baroroh with the tittle "Arabic Active Learning Model Model Belajar Bahasa Arab Efektif" and the other literatures as supporter. The teacher should has a good knowledge about strategy and method in arabic learning. And more than knowledge, the teacher should has competence to applicate and develope that. The explanation about strategy of learning the arabic elements for elementary level, including there the method and all of component is expected to be able give knowledge to the teacher so that can made the learning atmosphere be more efective and reach the learning goals.

\section{Result and discussion}

A human live in this world to know everything with a learning. The learning is a necessity for a human who has been given a cognitive competence with organs in his body like a brain, nerve and sense. One of the islamic doctrine dimentions that famous is 
instruction to learning and looking for a knowledge. ${ }^{10}$ The learning has been given the special space in the Islam so that include to pray when the moslem has learn with a goal to look for Ridho Allah.

Beside Islam has instructed the followers to learn and look for knowledge, it also has given a special award for everyone who learn, search a knowledge, develop themself, and over that a lot of dalil has described about students level example Allah said "say is there same between who know and do not know?" 11 One of the advices in the islam is learning arabic because the Holy Quran is given with arabic language like Allah said "Actually We send that in shape of Al-Quran with Arabic language for you understand that". ${ }^{12}$

In general, studying process is hold with teacher and students is the learning. In the language learning needed components that constructed between them for making a goal and reaching the success result. Every learning language can not run without a approach, method, media and strategy for reaching the learning goals quickly, effective and effisien. ${ }^{13}$ Zaini also said in his book "Desain Pembelajaran di Perguruan Tinggi" that the success learning related with the learning strategy and method. The right learning strategy will develope students to think independent, being creative and adaptive with every situation. ${ }^{14}$ To know learning strategy, the first step was the teacher should be understood the approach that was used in the learning which will be applicated, over there the teacher should be knew until the learning theory which was used as foundation.

Thu'aimah has classificated the language learning level to three levels, they are the elementary, intermediate and high level. Difference of that three levels are from using language aspect. Elementary level as the level which grow up the basic language skills for the students and make them can arrange the voice and the design. Intermediate level as the level which affirm the basic language skills, expand their knowlwdge, and add the vocabularies for the students. And high level aims to take the students controling language use. ${ }^{15}$

\section{Arabic Learning Approach for Elementary Level}

The Learning Arabic for elementary level was more suitable with the behaviorism learning theory. The implication of that in language learning especially in foreign language

10 Umi Mahmudah dan Abdul Wahab Rosyidi, Active learning dalam Pembelajaran Bahasa Arab (Malang: UIN Malang Press, 2008), 1.

11 QS Azzumar ayat 9

12 QS Yusuf ayat 2

13 Mustofa, Strategi Pembelajaran Bahasa Arab Inovatif, 3.

14 Asse, "Strategi Pembelajaran Bahasa Arab Di Insutut Agama Islam Negeri Palu," 452.

15 Rusydi Ahmad Thuaimah, Ta'lim Lughoh al-arabiyah lighairi al-nathiqin Biha Manhijuhu Wa Asalibuhu (Ribath: Esisco, 1989), 64. 
is come the structural linguistic in the structural drills mode and pattern practices, the verbal memorization, and giving rewards. ${ }^{16}$ Then, the learning theory that was used was developed to an asumtion that was called with approach in a learning.

The Approach in a learning is a set of the asumtion about the language essence and the language learning essence. ${ }^{17}$ The Approach in learning arabic was classificated to the categories which were an option for the teacher related with the learning goal, the student characteristics etc. This discussion analyzed the arabic learning for elementary level with comprehensive approach (الدخل التكاملي). The Comprehensive approach is a way to manage the language element experiences in the past for the student, the learning for reaching a relation, and the integration with a concept that can make them know the relation between that, the function in the language implementation, from the language content that has the element comprehensively, the relation in its guidelines and excercises, the grammar with its competences, kind of application that was asked from the poem text or essay, or the verbal position also non verbal, the teaching with the method that based on the integration and exercises, and then evaluate the students gradually. ${ }^{18}$ The comprehensive approach involved all of the students experiences in the learning a language, there were the knowledge, the competence, and the attitude of the student in the learning arabic.

Comprehensive approach gave an exprience completely for the elementary level student in arabic learning. Arabic learning needed a good consistence from the teacher or student so that can develope for all learning aspects goal, so comprehensive approach was an approah which can optimize all of students competences.

A knowledge about learning from the theory as a basic and choose a right approach gave a description for deciding what the method or strategy that will be used. Method and strategy in arabic learning supported a success learning achievement.

\section{Arabic Learning Method for Elementary Level}

The learning method is detail from theory and approach that is used in the learning. The method is one way that is used by the teacher to deliver a material in the learning. Abd Raziq (2007) said that the learning method (thariqah al-tadris/teaching method) is a planning level programe completely and relate with the steps of the learning material delivery procedurally, and not contradictive with the approac. In the other word, method is the theories application in the specific approach. The method is more operasional activity than

16 R. Umi Baroroh, Arabic Active Learning Model Model Belajar Bahasa Arab Efektif (Yogyakarta: Fakultas Ilmu Tarbiyah dan Keguruan UIN Sunan Kalijaga Yogyakarta, 2018), 19.

17 Rosyidi dan Ni'mah, Memahami Konsep Dasar Pembelajaran Bahasa Arab, 33.

18 Ahmad Abduh Udl, Madakhil ta'liimu allughah al-arabiyah (Saudi Arabia: Jami'ah umul qura, 2000), 21. 
the approach, there is selection of the competence that will teach, and so the material that will teach until its squence. ${ }^{19}$

The Success of the learning was depended on method application that has chosen by the teacher. The factors that have used as a reasoning to choose the learning method are: (a) adjusting the student's character, both the mind development and the social condition; (b) the teacher notice the general rule in deliver the lesson example from the easy to difficult, from the basic to complex; (c) considering student's skill from all aspects (cognitive, affective, and psychomotor); (d) making a conducive learning situation with still involve the student in the learning; (e) growing the student's concentration, motivation and creativity; (f) making the learning as a fun activity and useful; (g) following the basics of the learning, like give a reward, a fun exercises, and making them can do something. ${ }^{20}$

There are a lot of arabic learning methods in Indonesia: (a) grammatical and translate method; (b) direct method; (c) audiolingual method; (d) reading method; (e) eclectic method. 21 That various methods not just relate with one language competence or element, but also match with a development can make a new method with helping from the last method is eclectic method.

The last method that was mentioned was eclectic method or mix method, it was match of two learning methods that was appropriate with the learning type and goal. The learning for elementary level use the eclectic method will help the learning goal achievement with habituation in giving the learning material and application in the exercises. With this method, the students are given the exercises example a conversation, writing, reading and the other exercises. ${ }^{22}$ This method beside gave an intensity to the students in development of arabic skills also gave a new learning experience with teacher's creativity for upgrading the student's interest.

In a research about the learning for elementary level mentioned that this method is appropriate if it was used in a learning (the learning in that research is qawaid learning). ${ }^{23}$ The result of the research showed that student's learning achievement which they were given intiqa'iyyah method was higher than the students who were given the convensional method/Qawa'id and translate. That was caused by the learning with intiqaiyyah method

19 Acep Hermawan, Metodologi Pembelajaran Bahasa Arab (Bandung: Remaja Rosdakarya, 2011), 168.

20 Mustofa Bisri dan Abdul Hamid, Metode dan Strategi Pembelajaran Bahasa Arab (Malang: UIN MALIKI PRESS, 2012), 24.

21 Hermawan, Metodologi Pembelajaran Bahasa Arab, 169-96.

22 Mustofa, Strategi Pembelajaran Bahasa Arab Inovatif, 22.

23 Raswan Raswan, "PENGARUH METODE PEMBELAJARAN EKLEKTIK TERHADAP HASIL BELAJAR BAHASA ARAB SISWA," Arabiyat : Jurnal Pendidikan Bahasa Arab dan Kebahasaaraban 5, no. 1 (3 Juni 2018), https://doi.org/10.15408/a.v5i1.7007. 
more directed to dinamism of the learning. So the learning is not monotonous, and the opposite was flexible and fun for the students of the arabic learning.

That research also gave a reason why the eclectic method was appropriate to applicate in the learning. The reason is: first, every foreign language learning method has the excellence, so the teacher can take the excellences. Second, there is nothing perfect method and nothing bad method, but every learning method has an excellence and deficiency. Third, will be better if we have a view that a method will be perfect if we pair with the other method, and don't have an assumtion that between methods is contradictive. Fourth, no one methods was found suitable with all of the goals, students, and all of the curriculum types in the foreign language learning.

Fifth, the important one in the learning is focus on the students need, and don't think about what the method that is used. Sixth, the teacher must feel free to choose a technique that matching for the students, and not strange because just think using a lot of methods. but better if the teacher choose the right technique and suitable with the sutdent's need also the learning condition from the existing methods.

\section{Learning Arabic Strategy for Elementary Level}

Aside of the method that was an important part in the learning, the strategy also an important squence in the learning. The trategy is a system that is planned and decided intentionally to do the activity or the action. The strategy covers a goal, subject, content, proccess, and media that support the activity. and the learning is the teacher's effort to help the students in learning activity. in the learning, the students don't do the learning activity themself but study with the other people with thinking and action in their own world life. ${ }^{24}$

Asrori said that learning strategy is the method in a large meaning that covers the plan, implementation, evaluation, enrichment of knowledge, and the remidial as choosing and deciding the behavior transformation, approach of procedur, method, technique, and rules or limits of success. ${ }^{25}$ According to Mustofa, learning strategy is the ways that will be used by the teacher to choose a learning activity that will be used during the learning, and that selection is done with consider the situation and condition in achieving learning goal. 26 And so Arabic learning strategy is a way that is chosen and used by teacher in delivering the

24 Asse, “STRATEGI PEMBELAJARAN BAHASA ARAB DI INSUTUT AGAMA ISLAM NEGERI PALU," 455.

25 Mohammad Asrori, "Pengertian, Tujuan Dan Ruang Lingkup Strategi Pembelajaran," Madrasah 6, no. 2 (29 Januari 2016): 168.

26 Mustofa, Strategi Pembelajaran Bahasa Arab Inovatif, 9. 
arabic learning material to simplify the students in accepting and understanding the arabic learning material. ${ }^{27}$

That learning strategy was understood as a bridge where simplify the way of arabic learning and a big wish to help student's understanding. The various literatures said that student's language skill better with existence of language learning strategy than the students that don't use the strategy in the learning. (Cohen 1998; Harris 2003; McDonough 1999; O'Malley and Chamot 1990; Oxford 2001; Zhang 2003).28

There are elements in a strategy of the learning that are should be noticed in the pplication. The elements are ${ }^{29}$ :

1. Deciding spesification from qualification transformation of habbit, make the goal always as reference in planning and doing every learning activity.

2. Choosing learning approach, a view way in delivering that is planned for reaching the deciding goal.

3. Choosing and deciding learning method, technique, and proccedur.

Learning Arabic media for elementary level

Learning strategy also needs the media as a supporter in the application. One of the reason the teacher can more optimal when deliver the learning material is there is the support device that interesting for the students. The learning media can be interpreted as a tool or something that help the teacher in delivering the material learning for the goals can be delivered better. Like Gagne and Briggs said by Arsyad (2002) that the learning media covers the tool that physically is used to deliver the material content that are the books, tape recorder, cassette, video camera, video recorder, film, slide, photo, picture, grafic, television and computer. ${ }^{30}$ Along with the times and technology dvelopment, the learning media also follow the developmnt, so has knew an interactive media until now. Interactive learning media is a help tool based on multimedia that can explain a messege or information from the teacher to the students and there is a active communication between multimedia and the students on that proccess for easy learning proccess. ${ }^{31}$

The generation now is requiring the various media that support the knowledge delivery with the popular tool. And now is not leaving the modern technology like

27 Mustofa, 11.

28 Arif Ahmed Muhammed Hassan Al Ahdal, "Learning Strategies of the Arab EFL Learners: Finding Correlation with Outcomes," Advances in Language and Literary Studies 6, no. 5 (Oktober 2015): 231.

29 Asrori, "Pengertian, Tujuan Dan Ruang Lingkup Strategi Pembelajaran," 169.

30 Abdul Wahab Rosyidi, Media Pembelajaran Bahasa Arab (Malang: UIN Malang Press, 2009), 26.

31 "Software Pembuatan Media Pembelajaran Berbasis ICT," diakses 2 September 2018, https:/ / gurudigital.id/pengertian-contoh-dan-software-pembuat-media-pembelajaran-interaktif/. 
handphone that the function is like personal computer and is called android, so everyone may access everything and make it easy all of the aspect in the life, and on of it is the learning. it becomes the help for development of learning media so a lot of that develope applications whom can be instaled in the android device. And mentioned that the applications is part of interactive learning media.

Example of the learning media based on android application is KelasKita, this application has came with a various online class that can be followed. After we decided for following a class we will accept a material that is given step by step. Except that there is Ruangguru application, the RuangGuru application is possible for us to consultation about the learning material via chat or video call. So this application can be been a reference in the learning. ${ }^{32}$ That description also give a chance to Arabic learning in using the applications that available in playstore (a room to buy the application in android) for the learning more fun.

\section{Learning The Arabic Elements}

There is the elements and competences that is taught in the language learning. In the language elements there is phonology ('ilm ashwat), ortography (kitabat al-huruf), morphology (al-sharf), syntax (nahwu), and vocabulary (al-mufrodat). and the language competence is consists of reading (al-qiraah), writing (al-kitabah), speaking (al-kalam), and listening (al-istima'). ${ }^{33}$

From the various component is mentioned the language elements component, in the reality the elements that are often taught in the arabic learning are phonology (al-ashwat), vocabulary (al-mufrodat), and grammar (qowa'id). Learning the arabic elements for elementary level has given a strong influence to the arabic students because it has a basic in the arabic learning completely. Other than that a lot of the arabic students in Indonesia study arabic in the elementary level because feel to need a basic skill in the arabic for learning the religion and the others importance, not limit just to the formal students. Arabic learning that focus to grammar is so much in Indonesia, this learning is classificated to the arabic learning with special goal, and the dominan casse in Indonesia is the learning that just study the basic knowledge for sufficient the religion knowledge (reading, writing and translate a text). ${ }^{34}$ Learning the arabic elements can be described to:

1. Learning The phonology/'Ilm Ashwat

32 "Software Pembuatan Media Pembelajaran Berbasis ICT."

33 Effendy, Metodologi Pengajaran Bahasa Arab, 109.

34 Toni Pransiska, Pendidikan Bahasa Arab di Indonesia Historisitas dan Realitas (Yogyakarta: Penerbit Ombak, 2005), 105. 
Al-Ashwat is a voice, that is how someone say the voice in the arabic well and correctly as the arabian said. The essence of learning ashwat is understand and know the voice or sound, can differentiate between a voice with the other voice and can implement that into other format, or in the other language is called a phonology. The principal that is learned in this theme is the way to say the arabic voice correctly and fluently (makhraj huruf hijaiyah) when stand alone or when together with other huruf and harakat. ${ }^{35}$

The voice of the language is a language component that is met by the new students for the first time, therefor the voice must be taught by the right way since the beginning for making the students easy into resolve the arabic voice problem. So that the first thing that is resolved by the teacher is resolve the students's problem to say arabic sounds. That difficulty will be faced by the students because the character of the arabic voice system into several things is different with the other language, and can be happened because an influence of the mother language. ${ }^{36}$

The ashwat learning for elementary level also can use the direct method that is matche with audiolingual method. In the ashwat learning involve all of the competences especially listening so that besides the direct methid that give a treatment to the students for elementary level also can be added with audiolingual method.

In the ashwat learning for elementary level identify the learning designs, there are ${ }^{37}$ : a) design to observe the arabic voice, it is learning arabic with a goal to know the character in the sounds of huruf, word, phrase, sentence and stucture by listening, following and repeating the sound to fluently pronunciation without looking a note; b) design to following the sound; c) design to jahriyah reading (loudly reading).

The strategies that can be used in the ashwat learning for elementary level are:

1) The students Listened arabic sound start from hijaiyah alphabet with the right pronouncation. in this step used alphabetic method ${ }^{38}$ that is started with introduce the names of the alphabet with the writing, then it is introduced a consonan sound that is connected with vocal so that is produced a phonem. This step can be done with the design to observe the sound, then following and jahriyah reading. Example: the teacher wrote and said آ إ أ - بَّ بِ بُ - جَج جَ جُ then the students noticed and followed by reading even until followed the writing from the pronunciation that is listened without look the note.

35 Mustofa, Strategi Pembelajaran Bahasa Arab Inovatif, 27.

36 Mustofa, 36.

37 Baroroh, Arabic Active Learning Model Model Belajar Bahasa Arab Efektif, 174.

38 Mustofa, Strategi Pembelajaran Bahasa Arab Inovatif, 42. 
2) The students pronounced the arabic sound with followed the simple words until according to the pronunciation rules. In this step can use the design to observe the sound and following that. This step also can use sound methods by the synthetic, analytical, or the synthetic analytical. ${ }^{39}$ The sound method introduced the students to the sound without introduced alphabets, there were three ways that were used: 1) the synthetic way, it is started with introducing the sound of hijaiyah and that is arranged

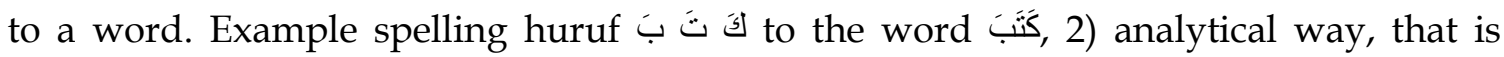
started with the word which is splited to the alphabets. Example the word عَ ع was

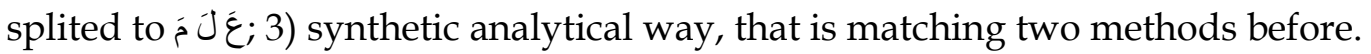

3) Identificated and differentiated the similiar sound and simple words. Same as the step before, this step used design to observe the sound and follow that, also used the sound method with this example: 1) the synthetic way, that was started with introduced the hijaiyah sound and was arranged to the word. Example spelled the hijaiyah كَّ تَّب

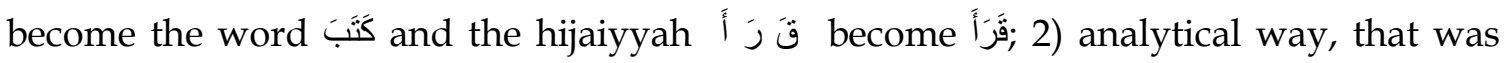
staarted with the word that was splited into the hijaiyyah next, the example was the

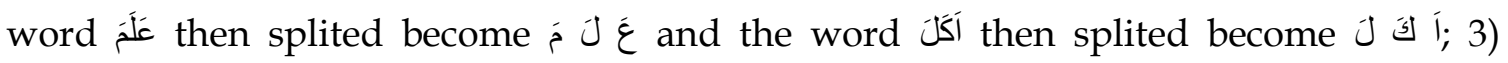
synthetic analytic way, that was matched two methods before.

4) Used the android application that was gave the arabic sound learning like this applications: 1) The pronounce of arabic alphabetic (makharijul huruf hijaiyah) that was produced by Kharisma studio, this application give the guidance for said the Arabic alphabetic (hijaiyah) with the right pronunciation, there is an information where is the makhroj was pronounced and the exersice of reading Al-Quran; 2) Makraj huruf that was produced by QT Media, this application was same as before, the is the ways to pronounce hijaiyah with the example; 3) Belajar bahasa Arab+Suara that was produced by Solite Kids, this application was suitable to the kids, there was Arabic themes that was completed with the picture and sound also games so the learning was be fun.

5) Made the guided exercises or the independent exercises for the better result in pronounced the arabic sound. The exercises that was given can use the design to observe the sound, followed the sound or jahriyah reading adjust where the part of skill that need to upgrade.

2. Learning the vocabulary

Kridalaksana in his linguistic dictionary (1983:13) defined the vocabulary of the people is a compilation by all of the words that is known by that people and may will be 
used to arrange the new sentence. Other than that the vocabulary is also defined as a batch of the words that make a language. The function of the vocabulary in knowing four language competences is very needed as said Vallet that the skill for understanding it is very depend on knowing of the vocabulary by someone. ${ }^{40}$

Learning a language can not be detached with what that is named the vocabulary learning, where it is one of the urgent element in the language learning. the vocabulary learning is not just teach the vocabulary and ask the students to memorize that, but over that the students is considered can know the vocabulary if can reach this indicators: 1) the students can translate shapes of the vocabulary well; 2) the students can pronounce and rewrite it well and correctly; 3) the students can use it into the right sentence, orally or writing. ${ }^{41}$

The vocabulary learning for elementary level can use the direct method that was matched with reading method. In the vocabulary learning involve all of the competences especially the reading so that other than direct method which give a treatment to the elementary level students is also can be added with the reading method.

In the ashwat learning for the elementary level know the designs of the learning as42: a) the design to observe, b) the translate design, c) doing assignment seriously design, d) Arabic practice in the class design, e) ready to study design, f) writing diary activity design, g) arabic practice in the class and home environment design.

The strategy that can be used in the vocabulary learning is like:

1) Giving the vocabulary with the meaning by the various ways. That can use a song, picture or the the object directly. ${ }^{43}$ This step can use the observe design.

2) Mention the vocabulary from the object or the picture there, like playing guessing games or asking quetion. This step can use the observe design and translating.

3) Reading and finding the meaning from the words in the sentence or simple text that was read. Asking the students to read many times so the students is expected can understand the meaning. ${ }^{4}$ This step use the observe design, trnslating, and practicing especially in the reading competence.

40 Riyadi, “Strategi Pembelajaran Bunyi Dan Mufrodat," 122.

41 Mustofa, Strategi Pembelajaran Bahasa Arab Inovatif, 60.

42 Baroroh, Arabic Active Learning Model Model Belajar Bahasa Arab Efektif, 176.

43 Mustofa, Strategi Pembelajaran Bahasa Arab Inovatif, 73.

44 Mustofa, 73. 
4) Use the application from the android, example this applications: a) Game Arab:Game Kata, the vocabulary game that was produced by Fun Word Games Studio, this application is a vocabulary game that accomodate many words and was designed easy for all of age; b) Learn Arabic Game that was produced by Elbahri Safari, this application is a game with matching the Arabic vocabulary with the suitable picture, it was designed with the interesting and fun pictures; c) Tebak Kata Bahasa Arab that was produced by QodrBee, this application is the arabic vocabulary game that consists of five level and every level must answer 20 vocabularies correctly, if the answer is false so can not continue to the next question.

5) The exercise to applicate into the language competence routinely so that the vocabulary continues to grow and more advanced. In this step including there that mentioned by Mustofa is listening and following a reading also writing that until the students is understand. ${ }^{45}$ In this step can use the observe design, doing the assignment seriously, practicing in the class or the environment, the ready to study is also can be used, and writing the activity as diary.

3. Learning the grammar/Qawa'id

The Qawa'id or Tarakib is the grammar in Arabic. The definition of the grammar is the media for using the language correctly in a communication, according with the grammatical of that language. Ilm al qawa'id in the outline consists of two parts, there are nahwu and sharf. Without a good skill of qawa'id, someone will have a lot of the problems in using active arabic and passive. ${ }^{46}$

The tarakib learning is delivered by three designs ${ }^{47}$ are qiyasy method (deductive), istiqraiy method (inductive), and al-mu'dilah (an-nash al-araby). The qiyasy method is the tarakib learning by explain the rules first and then continue with the examples and exercises. The istiqraiy method is the tarakib learning that give the examples first and then is explained the qowaid there. The al-mu'dilah method is also mentioned the continued design, that is a reading piece of the topic that is read by the students, then is showed a lot of points and the spesific things and next take the conclusion about the grammar and do the exercise.

From the designs that still have developed is the qiyasy method, that is explain the grammar and continue with the example and exercise. This design is still used because is considered effective applicated in the Arabic grammatical learning, 
the students give a positive response and develope their skills in the arabic learning. 48

The tarakib learning for elementary level can use the direct method that was matched by the reading method with analysis. In the grammar learning more involving reading and writing so other than direct method that give a treatment to the elementary level students, also can adding with a reading method with analysis.

In the grammar learning for elementary level identfy the learning designs as this ${ }^{49}$ : a) the design to observe; b) the design to do assignment seriously; c) the design to be ready in learning.

The strategy that can be used in the grammar learning for elementary level is like this:

1. Giving the sentence and the basic arabic gramatical rules or the opposite. It can be done by deductive or inductive depend on the students condition. This step use the design to observe.

2. Giving the simple examples to the grammars that have been explained. This step use the design to observe and ready in learning, with note the students was ready with the gramatical concept that was taught.

3. Asking the students to repeat the gramatical explanation and giving the different example from the examples that was given by the teacher. This step use the design to observe and ready in learning.

4. Applicate the material to the language competences especially to the reading and writing the sentence or simple text. This part use the design to observe and doing the assignment seriously.

5. Use the application in the android device about the tarakib learning, for the example this applications: a) BISA Bahasa Arab Nahwu Shorof is produced by BISA Foundation, this application is the learning Arabic online application that provide the various features start from text, picture to video, but for some features with better level use an online payment; b) Belajar Bahasa Arab Praktis is produced by Darussalam Learning Centre, this application is contained of the basic Arabic grammars and the general vocabulary; c) Nahwu Bahasa Arab Lengkap is produced by Ely's Studio, this application is contained of the arabic

48 Achmad Muhlis, "Pengembangan Model Pembelajaran Qawaid Sharraf Dengan Pendekatan Qiyasiyah di MTs Negeri Sumber Bungur Pamekasan," NUANSA: Jurnal Penelitian Ilmu Sosial dan Keagamaan Islam 13, no. 1 (30 Juni 2016): 33.

49 Baroroh, Arabic Active Learning Model Model Belajar Bahasa Arab Efektif, 193. 
grammar offline with the vocabulary, the examples and nadhom from nahwu books.

6. Doing the exercises about the grammar and the analysis of the example in the sentence or the text routinely. This step using the design to observe, the design to be ready in learning and doing the assignment seriously.

\section{Conclusion}

The arabic learning teach the arabic elements that consists of the language voice (ashwat), the vocabulary (mufrodat), and the grammar (tarakib). The arabic elements learning is done depend on the elementary, intermediate, and high level. Learning the arabic elements give the task to the teacher for stimulating the students to be active so the competence was upgraded in knowing all of the arabic elements. For supporting the learning strategy for the elementary level, the teacher can use the arabic learning applications that was available in android device and easy to be accesed by the students. In each element of the arabic elements is explained the learning procedure that consists of the grammar explanation that must be noticed by the students and to be followed, the examples, the exercises and applicate into the language competences.

\section{Bibiliography}

Al Ahdal, Arif Ahmed Muhammed Hassan. "Learning Strategies of the Arab EFL Learners: Finding Correlation with Outcomes." Advances in Language and Literary Studies 6, no. 5 (Oktober 2015).

Asrori, Mohammad. "Pengertian, Tujuan Dan Ruang Lingkup Strategi Pembelajaran." MADRASAH 6, no. 2 (29 Januari 2016): 26. https:/ / doi.org/10.18860/jt.v6i2.3301.

Asse, Ahmad. "STRATEGI PEMBELAJARAN BAHASA ARAB DI INSUTUT AGAMA ISLAM NEGERI PALU." ISTIQRA 2 (2) (2 Desember 2014): 22.

Astuti, Widi. "BERBAGAI STRATEGI PEMBELAJARAN KOSA KATA BAHASA ARAB." Jurnal Komunikasi dan Pendidikan Islam 5 (1) (Desember 2016): 15.

Baroroh, R. Umi. Arabic Active Learning Model Model Belajar Bahasa Arab Efektif. Yogyakarta: Fakultas Ilmu Tarbiyah dan Keguruan UIN Sunan Kalijaga Yogyakarta, 2018.

Bisri, Mustofa, dan Abdul Hamid. Metode dan Strategi Pembelajaran Bahasa Arab. Malang: UIN MALIKI PRESS, 2012.

Effendy, Fuad. Metodologi Pengajaran Bahasa Arab. Malang: Misykat, 2009.

Hasnah, Sitti. "PEMBELAJARAN KOSAKATA (MUFRADĀT) BAHASA ARAB MELALUI MEDIA GAMBAR UNTUK MENINGKATKAN MINAT BELAJAR MAHASISWA PADA JURUSAN PAI FAKULTAS TARBIYAH IAIN PALU," t.t., 29.

Hermawan, Acep. Metodologi Pembelajaran Bahasa Arab. Bandung: Remaja Rosdakarya, 2011.

Mahmudah, Umi, dan Abdul Wahab Rosyidi. Active learning dalam Pembelajaran Bahasa Arab. Malang: UIN Malang Press, 2008.

Muhlis, Achmad. "PENGEMBANGAN MODEL PEMBELAJARAN QAWAID SHARRAF DENGAN PENDEKATAN QIYASIYAH di MTs NEGERI SUMBER BUNGUR 
PAMEKASAN." NUANSA: Jurnal Penelitian Ilmu Sosial dan Keagamaan Islam 13, no. 1 (30 Juni 2016): 23.

Muradi, Ahmad. “TUJUAN PEMBELAJARAN BAHASA ASING (ARAB) DI INDONESIA." Al Maqoyis 1 (1), no. 1 (Juni 2013): 10.

Mustofa, Syaiful. Strategi Pembelajaran Bahasa Arab Inovatif. Malang: UIN MALIKI PRESS, 2011.

Pransiska, Toni. Pendidikan Bahasa Arab di Indonesia Historisitas dan Realitas. Yogyakarta: Penerbit Ombak, 2005.

Raswan, Raswan. "PENGARUH METODE PEMBELAJARAN EKLEKTIK TERHADAP HASIL BELAJAR BAHASA ARAB SISWA." Arabiyat: Jurnal Pendidikan Bahasa Arab dan Kebahasaaraban 5, no. 1 (3 Juni 2018). https://doi.org/10.15408/a.v5i1.7007.

Riyadi, Sugeng. “STRATEGI PEMBELAJARAN BUNYI DAN MUFRODAT” 3, no. 2 (2014): 21.

Rosyidi, Abdul Wahab. Media Pembelajaran Bahasa Arab. Malang: UIN Malang Press, 2009.

Rosyidi, Abdul Wahab, dan Mamlu'atul Ni'mah. Memahami Konsep Dasar Pembelajaran Bahasa Arab. Malang: UIN Malang Press, 2012.

Setyawan, Cahya Edi. "PEMBELAJARAN QAWAID BAHASA ARAB MENGGUNAKAN METODE INDUKTIF BERBASIS ISTILAH-ISTILAH LINGUISTIK." Jurnal Komunikasi dan Pendidikan Islam 4, no. 2 (Desember 2015): 15.

"Software Pembuatan Media Pembelajaran Berbasis ICT." Diakses 2 September 2018. https://gurudigital.id/pengertian-contoh-dan-software-pembuat-mediapembelajaran-interaktif/.

Thuaimah, Rusydi Ahmad. Ta'lim Lughoh al-arabiyah lighairi al-nathiqin Biha Manhijuhu Wa Asalibuhu. Ribath: Esisco, 1989.

Udl, Ahmad Abduh. Madakhil ta'liimu allughah al-arabiyah. Saudi Arabia: Jami'ah umul qura, 2000. 